\title{
Lack of Proficiency in English Language: Understanding the Circumstances among the Military Cadets
}

\author{
Haida Umiera Hashim ${ }^{1}$, Melor Md Yunus², Harwati Hashim* \\ \{*harwati@ukm.edu.my\} \\ Faculty of Education, National University of Malaysia (UKM), Selangor, Malaysia
}

\begin{abstract}
Globalisation has driven university students in today's era to be more proficient in English language. Being proficient in English language is to be considered an advantage for university students to survive in their tertiary level of education, also in reserving work spot in the future. There have been many strategies and tactics employed by educators all around the world to help learners to be more proficient in English language. However, regardless of all the effort, there are still tons of university students who are not quite proficient in English language. Therefore, it is believed that there is a need for us to figure the main circumstances that may lead to the barrier towards good proficiency among learners; university students especially. Hence, a qualitative study using open-ended questionnaire is conducted to investigate the factors and circumstances towards lack of proficiency in English language university students. Twenty two undergraduate students of ESL Learning majoring in Computer Science courses responded to the questionnaire. The findings have shown that there are three main circumstances that they think have made quite of an impact towards their lack of proficiency in English language namely; the struggle of learning English, lack of confidence and low self-esteem and environmental factors. Further discussion and recommendations are discussed in this study.
\end{abstract}

Keywords : Language, Proficiency English, Military

\section{Introduction}

English language is to be considered as an international language and is taught widely all over the globe [1][2]. Globalisation and fourth industrial revolution is one of the proofs of how English language is undeniably crucial in today's era. English language is not only used in both primary and secondary level of education, but English language is also widely used in tertiary level of education. Most books are in English and even most of the lectures are conducted in English language. Not being able to understand and fully comprehend English language will cause university students to be left behind and struggle to survive in their tertiary level of education. Being proficiency in English language also helps individuals, especially university students in reserving work spot in the future. Work industry in today's world are demanding for their workers to be fluent in English language alongside with good soft skills. However, the concerning issue is that today's younger generations are lacking in English proficiency regardless of all efforts that have been created and implemented to help university students to acquire good English language. Therefore, in conjunction to this matter, 
it is believed that there is a need for a study on seeking and investigate the core of this problem. Hence, the purpose of this study is to identify the circumstances and reasons behind the lack of proficiency in English language based on the perspective of university students.

English language is the universal language that is used even when you go for travelling, let alone to seek for job in the future. Speaking is to be said as the modus operandi of any language [3]. English language learning and acquisition is quite of a complex process [4]. English language basically comprised of a few main skills namely reading, writing, listening and speaking skills and speaking skills is to be said as one of the hardest skills for learners to acquire. Different learners have different styles of learning English language [2]. Same goes to the level of motivation in learning English language. [5] in their study have investigated the attitudes and motivation level of ESL learners towards ESL learning. They have figured out that different students have different attitudes and level of motivation towards English language learning and acquisition. Previously not many learners are well aware of the importance of English language, however, many have realised the importance of English language in today's world and have started to take English language learning seriously especially speaking skills. One of the reasons that lead to this is due to the globalisation in today's era that makes the ability to speak and be proficient in English language as a crucial aspect in both education and working field. [3] in their study mentioned the importance of speaking in today's world. As English language is widely used in all over the world, speaking ability in English language is pretty much crucial and necessary.

[2] stated that English language has booked its name as one international language that is widely used all over the globe. The status of English language especially in Malaysian context has been previously clearly clarified by [6] in their study. They believed that English language in recent years has been an asset to acquire knowledge and to achieve development. It is pretty obvious up until now that learners, especially university students are still struggling with speaking skills regardless of the implementation and strategies done by the government to further improve Malaysian students' level of proficiency. The issue of proficiency skills among ESL learners in Malaysia has also been discussed by [7] in their paper on environmental conditions for English language learning in Malaysia. They have proven how Malaysia is not to be considered as an English language friendly which somehow causes learners lack of social interactions using English language making them to be lacking in proficiency. Both studies believed that an appropriate approach and teachings materials need to be selected if we were to face today's reality. [2] also proposed the implementation of Strategies Based Instruction (SBI) in the teaching and learning of English language in order to help learners to acquire good speaking skills. [8] in their study on practice and challenges of English oral communication in public secondary school in Kazakhstan believed that learners' production of oral language can be categorised into three groups namely; learner-related, teachers-peers-family related, and sociocultural factors.

This is also supported by an underpinning theory of this paper which is the theory of constructivism by Lev [9]. According to Vygotsky, Social Development Theory is very much needed in helping learners to acquire good proficiency skills. Social Development Theory is the foundations for constructivism. Vygotsky believed that learners learn to acquire the language best through social interactions and good social environment. This is also further agreed by [4] in their study on strategies of successful language learners among private school students. They have proven that metacognitive and social strategies play an important role in learners' strategy use. Lack of all this tend to put learners in a situation of speaking anxiety. Speaking anxiety is the uncomfortable feeling encounter by learners when they are needed to speak or communicate in certain language [10]. [10] in his study on speaking anxiety believed 
that learners do not feel comfortable in communicating in certain language, in this situation is English language is due to their limited knowledge and also fear of negative evaluation. They mostly do not consider making errors as part of the learning process but instead take it personally and think that it might affect their image.

\section{Methodology}

This study employed a qualitative design of study using open-ended questions. Twenty two English as Secondary Language (ESL) undergraduate learners from National Defense of University Malaysia (NDUM) majoring in Computer Science were requested to respond to the open-ended questions. The respondents are to be considered as an intermediate level of proficiency learners. Their feedbacks on the cause and circumstances that lead to the lack of English language proficiency were gathered then analysed.

\section{Result and Discussion}

A total number of twenty two students of undergraduate students majoring in Computer Science course responded to the open-ended questions. Their thoughts and feedbacks on the circumstances towards lack of proficiency in English language among university students are taken into considerations then later analysed. The findings gathered then are categorised into categories; A)The struggle of learning English, B) Lack of confidence and low self-esteem, C) Environmental factors.

\subsection{The struggle of learning English}

A few of the respondents mentioned that English is a language or a subject that is quite hard to learn. They considered English language as a language that takes quite a time to acquire. English language basically is divided into a few skills namely reading, writing, listening and speaking [10]. It is proven by quite an abundance of researchers all over the world on how speaking skills is the toughest skill for learners to acquire [2]. This is also agreed by [4] on how it takes experiments of language learning strategies for learners to be fully aware on their preferences in learning a language. Other than that, some of the respondents also mentioned that the lack of knowledge that they have in English language, especially in vocabulary and grammar is also one of the causes towards lack of proficiency in English language. Due to all this, they tend to be not motivated to learn English language let alone to improve themselves in being proficient in English language. Surprisingly, one of the respondents mentioned on the restriction of learning English language due to money constraint. The respondent stated that majority of the parents cannot afford to send their children to private English classes which makes them to be left behind in English language learning in comparison to other privileges learners who got the chance to attend English classes and tutors in order to improve themselves in learning the language.

\subsection{Lack of confidence and low self-esteem.}


Majority of the respondents stated that lack of confidence and low self-esteem is one of the biggest factors that leads to the lacking of proficiency among learners. Some of them are afraid and shy of communicating using English language in front of other people due to the feeling of being judged by other people. Some encounter speaking anxiety when it comes to speaking using English language. [10] agreed on this issue of speaking anxiety as he believed that some learners can get very intimidated and scared of judgements from the people surrounding due to lack of knowledge in the language. They tend to be nervous whenever they have to speak or communicate in English language. Their lack of knowledge in English language, especially pronunciation and grammar wise making them to have the anxiety and low self-esteem to communicate using English language. They tend to get afraid of making grammatical mistakes and even pronunciation mistakes. Due to this, they decided to stay in their comfort zone and speak using their mother tongue instead which is the Malay language. The problem of low self-esteem also happens when the learners tend to get intimidated by their other friends who are good and proficient in English language. Quoting one of the respondents that has stated his feedback regarding this issue of low self-esteem, '...lacking confidence or feel inferior agains those with good English'. This has caused them to be more self aware and more cautious whenever they are needed to speak in English language. Being extra self cautious tend to make them to be more passive and not wanting to participate in communicating using English language.

\subsection{Environmental factors}

Environmental factors described by the respondents are more likely on the issue of lack of support from people surroundings, lack of chances to practice communicating using English language, and judgemental mindset from people surrounding. Some of the respondents have the perception of that learning English language is not important. They perceived that being proficient in English language is not important which is why they prefer to speak and communicate using their mother tongue. Other than that, they also believed that one of the contributing factors of the lacking of English proficiency is due to the unhealthy environment of which where people are being judgemental and thinking that those who speak and communicate in English language only intended to show off. There is no sense of improving themselves in English language among the people surrounding making them to feel demotivated to improve themselves in English language. Lack of practice and chances to practice is to be said as one of the circumstances. The respondents stated that they do not have the environment that allows them to communicate in English language. Obviously English language is a second language and their mother tongue is the first language, making English language to be abandoned especially in daily conversations at home and with friends. Lack of chances to communicate in English language making the process for learners to acquire and be more proficient in the language to be tougher. Basically, practices makes perfect is the drill of everything especially in learning and acquiring a language. Not being able to practice is what making learners to be less proficient in the acquiring the language. Many researchers namely [7], [6] and [4] have proven how social and surrounding contribute to an important role in helping ESL learners to acquire good English language. [4] further emphasised in their study that acquiring a language is not only through cognitive but also metacognitive and through social interactions. 


\section{Conclusion}

Learning a language, especially English language takes effort and tons of practices along with the willingness to learn. To be proficient in English language means that more practices of communicating using the language is needed. It is proven that there are so many barriers and circumstances that might lead to the lack of proficiency among learners. Learners should be more aware of their language learning strategies and start to employ the strategies that they think will work for themselves in order to acquire good proficiency level of English language. Educators and managements at the same, should be more positive towards the use of English language during the process of teaching and learning and providing good environment would be as equally important for learners' development of proficiency in English language.

\section{Acknowledgement}

This research is supported by Universiti Kebangsaan Malaysia under research scheme no. GG-2018-001.

\section{References}

[1] Schlueter AL. Learning English for Young Learners "The Aspect of Intercultural Dimension, Diversity Arts and Media in the Early Foreign Language Education". InSixth of International Conference on English Language and Teaching (ICOELT 2018) Atlantis Press.2019.

[2] Nasir A. Implementing SBI (Strategies-Based Instruction) in Teaching Speaking Skills. strategies.7(1\&2):35-45. 2016.

[3] Quiroz MA, Cifuentes PJ, Rivera MO, Arcos LA. Developing the students' English speaking ability through picture description, picture narrating, and picture situation. 2018.

[4] Ang S, Embi MA, Yunus MM. Strategies of Successful English Language Learners among Private School Students. Jurnal Pendidikan Humaniora. 5(2):47-57. 2017.

[5] Hashim HU, Yunus MM, Hashim H. BITESIZE LEARNING: WHATSAPP STATUS FOR ENGLISH COMMUNICATION SKILLS. EDUINNOV TION. 8. 2018.

[6] Thirusanku J, Yunus MM. Status of English in Malaysia. Asian Social Science.10(14):254. 2014.

[7] Saad NS. Environmental Conditions for English Language Learning in Malaysia. European Journal of Language and Literature.1(3):100-11. 2015.

[8] Ismail K, Tuspekova A, Mustaffa R. English Oral Communication in Public Secondary Schools in Kazakhstan: Understanding its Practice and Challenges. 3L: Language, Linguistics, Literature®. 24(2). 2018.

[9] Pass S. Parallel paths to constructivism: Jean Piaget and Lev Vygotsky. IAP. 2004

[10] Ansari MS. Speaking anxiety in ESL/EFL Classrooms: A holistic approach and practical study. International Journal of Education Investigation. 2(4):38-46. 2015. 